\title{
THE SIXTH PACIFIC SCIENCE CONGRESS
}

\begin{abstract}
7 HE immense area of the Pacific Basin comprises what is perhaps the most fascinating region of the globe. It is bounded on the east, on the north and, as far south as the equator, on the west by volcanic regions indicative of great geological instability. It includes open stretches of sea hundreds of thousands of square miles in extent and contains more than twenty thousand islands, some of them rocky, others volcanic and others again of coral origin. These islands have a distinctive and in many respects a unique fauna and flora. They are populated by most interesting native races, Polynesians, Melanesians and Micronesians, who, coming originally from south-east Asia, settled these widely scattered islands by the most remarkable of all human migrations. There they evolved a civilization which evoked the amazement of those early European navigators who, however unwittingly in many cases, sowed the first seeds of its subsequent rapid decay.
\end{abstract}

Despite the great pioncer voyages of Spanish, Dutch, British, French and Russian navigators and of New England whalers in the seventeenth and eighteenth centuries and of scientific explorations such as those of the Challenger and of the United States exploring expedition under Wilkes in the ninetcenth century, the area covered by scientific and commercial surveys up to the beginning of the present century has been aptly described as no more than "a plough furrow in a twenty acre field". To quote from the introductory speech to the Sixth Pacific Congress of Prof. Herbert E. Gregory, former director of the Bernice P. Bishop Museum, Honolulu, and the greatest individual force behind modern scientific study of the Pacific: "The material and records amassed by such long timo undertakings as the Wilkes and the Challenger expeditions and during the first two decades of the present century by local surveys under the auspices of scientific institutions in England, Scandinavia, Australia, Netherlands Indies, Japan, Canada and the United States is large in bulk and variety. But its study reveals far more questions than answers. It shows that the Pacific is fairly bristling with problems in geography, geology, botany, zoology and anthropology and that the observations recorded here and there in a region that comprises more than a third of the earth's surface aro inadequate for comparative studies of the earth's physical features and of the origin, migrations and environment of living forms on the land and in the sea; and that until further knowledge has been gained many of the stories that science has to tell must be incomplete".

Co-ordinated scientific study of the Pacific was discussed at the meeting of the British Association in Australia in 1914 and afterwards in the United States. But it was not until 1920 that, largely owing to the initiative of Prof. Gregory, the first Pacific Science Congress met at Honolulu. This took the form of an informal gathering of some sixty carefully selected delegates from the United States, Canada, Hawaii, the Philippines, the Netherlands Indies, Japan, China, Australia, New Zealand and Samoa. It was realized that a central organization and planned expeditions were impracticable owing to lack of funds, but that a purely volunteer organization could play a great part in the furtherance of research in the Pacific if each unit, while perfecting its own programme, subscribed to a common programme and kept in close touch with associated organizations in other countries bordering the Pacific. While official delegates have been sent by interested Governments to subsequent congresses, these have always consisted essentially of individuals interested in various aspects of research in the Pacific area. This emphasis on the individual rather than on the Stato and on subjects of general sciontific interest, to the exclusion of anything likely to have a political bearing has been the key to tho subsequent outstanding success of the Pacific Science Association.

The second Pacific Science Congress was held in Australia in 1923, the third in Japan in 1926, the fourth at Java in 1929 and the fifth in British Columbia in 1933. It was there agreed that the sixth congress should not meet in North America, and the possibility of a congress at Fiji was discussed. This later proved impracticable, while international difficulties steadily increased so that tho maximum period of five years between successive congresses was passed without another meeting being arranged. But representations made at Washington to tho National Research Council of the United States most fortunately provented what, as later ovents have shown, would almost certainly have been a complete break in the continuity of these congresses.

Under the auspices of the National Research Council a sixth Pacific Science Congress was organized and held in and around San Francisco during July 24-August 12, 1939. The meetings wero held at Berkeley, Stanford and San Francisco, the University of California and Stanford University acting as joint hosts, and the Golden Gate International Exposition co-operating with them through its Department of the Pacific Area. Prof. Ross G. Harrison was president, and Prof. Roy E. Clausen, secretary-general, of the Congress.

The courageous optimism of these responsible for the organization of the Congress was abundantly justified by the presence of some five hundred delegates, including ropresentatives from Australia, Canada, China, Columbia, France, Great Britain, Hawaii, Hong Kong, Japan, the Netherlands and the Netherlands Indies, New Zealand, the Philippines, Siam, Sweden, the U.S.S.R., and the United States. The discussions covered a wide field, as may be indicated by the nature of the sections and subsections into which the Congress was divided.

Section 1, Geophysics and Geology, dealt with the structure and dynamics of the Pacific.basin; section 2, Oceanography and Marine Biology, including Fisheries, with the properties, dynamics and life of the Pacific. Pacific climates formed the subjectmatter of section 3 , which discussed past climates and also present climates under the two headings of meteorology and climatology. Section 4, Anthropology, dealt with man and culture in the Pacific region and 'with the objectives and results of the study of these cultures. Section 5 was concerned with the terrestrial faunas of the Pacific islands and bordering countries, and was especially concerned with systematic and economic entomology, including 
biological control of insect pests, and with medical entomology. General botany and plant diseases of the Pacific region constituted the two subsections of section 6 . Section 7 consisted of public health and nutrition, and was divided into subsections dealing with the geography and epidemiology of the communicable diseases of the Pacific region, with health hazards arising from transport, occupation and agricultural practices, with nutritional problems and finally with education in matters of health. Section 8 dealt with the characteristics, utilization and conservation of the soils in the countries of the Pacific.

All who are in any way interested in the manifold scientific problems of the Pacific owe a debt of gratitude to the National Research Council of the United States and to all who pressed, against considerable and not unnatural opposition, for the holding of this Congress. Thero must be many of the foreign delegates who now feel, with the writer, that this meeting, attended by so many races and nationalities united in the prosecution of disin. terested scientific research, will bo during the darkness which looms ahead both a memory of a happier past and a foretaste of a more enlightened future. The Congress broke up in the expectation of a seventh Congress to be held in the Philippines in 1943. That the future courso of world history makes this possible may well be the wish of every civilized human being.

\section{LOWER PERMIAN INSECTS OF KANSAS}

F. M. CARPENTER has recently discussed 1 . numerous specimens of fossil insects obtained in 1935 from the Elmo limestono (Kangas), of Lowor Pormian ago (Proc. Amer. Acad. Arts and Sci., 73, $29-70$; 1939). More than 8,000 specimens from this formation are now in the collections of the Harvard Museum of Comparative Zoology.

The results of the 1935 collection exceed all others in the number of complete, or nearly completo, specimens that wero disclosed. Some of the most interesting fossils obtained aro members of the group which Tillyard named the Protohymenoptera, and now regarded as belonging to the Megasecoptera. Thus, in Permohymen, the male genitalia aro woll preserved and aro seen to bo composed of paired penes with two-segmented claspers which are ovidently homologous with tho styli of may-flies. Regarding Asthenohymen dunbari, 32 specimens were found, and, of these, four present enough of the body structure to allow, for the first time, a complote reconstruction of the insect to be made and the differences between the fore and hind wings to bo ascertained. In one example the ovipositor is woll preserved.

The Protodonata that wero collected on the 1935 expedition proved to bo unusually interesting. In the first place tho discovory of Meganeuropsis permiana gen. et. sp. nov. from the Permian of Elmo constitutes the first example of a Meganeurine occurring in the
New World and also in rocks of Permian date. Dr. Carpenter discusses the affinities of the family Meganeuridx, and does not accept Martynov's con. tention that they should be placed in the order Odonata as true dragonfies: he concludes that there is no justification for thoir separation from the Protodonata until it is proved that the Meganouridx had a phylogenotic origin different from that of the other families of that order.

The author then passes on to deal with the Homoptera. Altogether twenty-six specimens belonging to this group wore collocted. While none of the species is new, the material adds to knowledgo of the body structure and the hind wings of the Homoptera. In Permoscytina kansasensis Till. tho single specimen obtained during 1935 shows a long process extending straight back from the end of the abdomen : being $9 \mathrm{~mm}$. long, it exceeds the length of the combined thorax and abdomen. Dr. Carpenter concludes that it is not an ovipositor but rathor of the nature of a respiratory tube such as is found in water bugs of the recent family Nepida. This contention presupposes that tho insect was aquatic, but there appears to be no indication of any modifica. tion of the rest of the body from an aquatic environ. ment, a feature shown in the recent family Nepidx.

The remainder of the paper deals with the Psocoptera, Protelytroptera and Protoperlaria.

A. D. I.

\section{INVENTIONS AND PATENTS IN GREAT BRITAIN*}

\begin{abstract}
$\mathrm{T}$
HE fifty-sixth report of tho Comptroller-General of Patents, Designs and Trade Marks for 1938, records a further increase in the number of patents, applications having increased from 36,266 in 1937 to 37,973 in 1938 , with increases in the number of provisional and complete specifications from 21,745 and 22,215 , respectively, to 26,696 and 23,098 . In regard to the trend of inventions, the synthetic

* Patents, Designs and Trade Marks. Fifty-sixth Report of the Comptroller-General of Patents, Designs and Trade Marks, with Appendices, for the Year 1935. Pp. 26. (London: II.M. Stationery Office, 1939.) $6 d$. net.
\end{abstract}

production of artificial wool and rubber, the latter by the polymerization of diolefines and halogenated diolefines, continues to be prominent. New devolopments in the very active field of synthetic resins are the use of polyamide resins for making artificial yarn and the use of resins in water purification by ionic exchange. Antioxidants or stabilizers for rubber, oils, fats, soaps, aldehydes and light-sensitive substances are much in evidence. Applications relating to azo and vat dyes decreased in number, but the develop. ment of long-chain polymethino dyes for use as photographic sensitizers is actively sustained. 